\title{
Effects of solar radiation on growth, photosynthesis and respiration of marine macroalgae from the Arctic
}

\author{
José Aguilera*, Ulf Karsten, Heike Lippert, Barbara Vögele, Eva Philipp, \\ Dieter Hanelt, Christian Wiencke
}

Alfred Wegener Institute for Polar and Marine Research, Am Handelshafen 12, 27570 Bremerhaven, Germany

\begin{abstract}
The effect of artificial ultraviolet (UV) and natural solar radiation on photosynthesis, respiration and growth was investigated in 14 red, green and brown macroalgal species on Spitsbergen (Norway) during summer 1998. In June, maximum mean solar radiation at sea level was $120 \mathrm{~W} \mathrm{~m}^{-2}$ of visible ( 370 to $695 \mathrm{~nm}$ ) and $15 \mathrm{~W} \mathrm{~m}^{-2}$ of UV radiation ( 300 to $370 \mathrm{~nm}$ ), and decreased gradually until the end of the summer. In spite of incident irradiance, levels were low in comparison with other latitudes, and UV radiation stress on growth of Arctic macroalgae was evident. Transplantation experiments of plants from deeper to shallow waters showed, for most algae, an inhibitory effect of both UVA and UVB on growth, except in the intertidal species Fucus distichus. The growth rate of selected macroalgae was directly correlated to the variations in natural solar radiation during the summer. Underwater experiments both in situ and using UV-transparent incubators revealed a linear relationship between the depth distribution and the growth rate of the algae. In almost all species the photosynthetic oxygen production decreased after $2 \mathrm{~h}$ incubation in the laboratory under $38 \mu \mathrm{mol} \mathrm{m} \mathrm{m}^{-2} \mathrm{~s}^{-1}$ photosynthetic active radiation (PAR 400 to $700 \mathrm{~nm}$ ) supplemented with $8 \mathrm{~W} \mathrm{~m}^{-2}$ UVA $\left(320\right.$ to $400 \mathrm{~nm}$ ) and $0.36 \mathrm{~W} \mathrm{~m}^{-2}$ UVB ( 280 to $320 \mathrm{~nm}$ ) compared to only PAR without UV. Like in the growth experiments, the only exception was the brown alga $F$. distichus, in which photosynthesis was not affected by UV. The degree of inhibition of photosynthesis showed a relation to the depth distribution, i.e. algae from deeper waters were more inhibited than species from shallow waters. In general, no inhibitory UV effect on respiratory oxygen consumption in all macroalgae studied was detected under the artificial radiation regimes described above, with the exception of the brown alga Desmarestia aculeata and the green alga Monostroma arcticum, both showing a significant stimulation of respiration after $2 \mathrm{~h}$ of UV exposure. The ecological relevance of the seasonal variations in the solar radiation and the optical characteristics of the water column with respect to the vertical zonation of the macroalgae is discussed.
\end{abstract}

KEY WORDS: Arctic macroalgae - Growth - Oxygen evolution · Photosynthesis - Respiration · Ultraviolet radiation

\section{INTRODUCTION}

In recent years stratospheric ozone concentrations decreased considerably, in particular in the polar regions, and resulted in enhanced biologically harmful ultraviolet (UV) radiation at the earth's surface. Compared to values in the 1970 s surface erythemal UV doses in spring increased by about $130 \%$ in the Antarctic and

\footnotetext{
•E-mail: jaguilera@uma.es
}

by approximately $22 \%$ in the Arctic (Madronich et al. 1998). The UV waveband of the solar radiation has been reported to penetrate to considerable depths in marine pelagic and benthic ecosystems (Franklin \& Forster 1997, Häder et al. 1998, Boelen et al. 1999).

Many life processes of marine primary producers are affected by UV radiation from the level of molecules up to that of communities. To date, damage of biomolecules such as DNA and proteins, supression of algal physiology and metabolism, and changes in marine community structure have been reported (Jokiel 1980 . 
Strid et al. 1990, Karentz et al. 1991, Smith et al. 1992, Buma et al. 1995, 1997, Davidson et al. 1996), all of which may affect cell division, mortality and consequently marine productivity (Häder et al. 1998).

Although an increasing number of studies demonstrate diverse deleterious effects of UV radiation on the photosynthetic characteristics of macroalgae (Forster \& Lüning 1996, Dring et al. 1996a,b, Figueroa et al. 1997. Hanelt et al. 1997, Bischof et al. 1998a,b), no general patterns have been discerned. This situation may be due to species-specific responses, acclimation to specific habitats (Dring et al. 1996a), or simply the low number of species studied so far. In this context, the studies conducted on some selected macroalgae collected from different depths in Arctic waters indicate that the degree of inhibition of photosynthesis after exposure to UV is related to the original growth depth (Hanelt et al. 1997, Bischof et al. 1998b). The higher insensitivity of shallow-water brown algae to UV radiation compared to deep-water individuals of the same species is reflected by a smaller decline in the optimum quantum yield $\left(F_{m} / F_{v}\right)$ which equals the degree of photoinhibition, as well as by a faster recovery after UV offset (Hanelt et al. 1997, Bischof et al. 1998a). The Arctic macroalgae studied by those authors seem to exhibit an effective physiological acclimation to increasing doses of UV radiation. The ability to resist high radiation stress may be one of the major factors controlling vertical macroalgal zonation patterns on communities (Bischof et al, 1998b, Hanelt 1998).

While at least some basic information on UV effects on macroalgal photosynthetic performance are avail-

Table 1. Investigated macroalgal species from the Arctic islands of Spitsbergen (Norway) and their occurrence in the eulittoral $(0 \mathrm{~m})$, upper sublittoral $(0$ to $2 \mathrm{~m})$, and lower sublittoral ( 2 to $20 \mathrm{~m}$ ) zones (Svendsen 1959, Klekowski \& Weslawski 1995)

\begin{tabular}{|ll|}
\hline Species & Habitat \\
\hline Chlorophyta & \\
Acrosiphonia penicilliformis (Fosl.) Kjellm. & Eulittoral-upper sublittoral \\
Monostroma arcticum Wittrock. & Upper sublittoral-lower sublittoral \\
Phaeophyta & \\
Desmarestia aculeata (L.) Lamour. & Lower sublittoral \\
Fucus distichus L. & Eulittoral-upper sublittoral \\
Laminaria digitata (Huds.) Larnour. & Upper sublittoral-lower sublittoral \\
Laminaria saccharina (L.) Lamour. & Upper sublittoral-lower sublittoral \\
Laminaria solidungula J. Agardh & Lower sublittoral \\
Saccorhiza dermatodea (Pyl.). J. Agardh & Upper sublittoral-lower sublittoral \\
Rhodophyta & \\
Devaleraea ramentacea (L.) Guiry & Eulittoral-upper sublittoral \\
Odonthalia dentata (L.) Lyngb. & Lower sublittoral \\
Palmaria palmata (L.) Grev. & Upper sublittoral-lower sublittoral \\
Phycodrys rubens (L.) Batters & Lower sublittoral \\
Phyllophora truncatia (Pal.) Zinova & Lower sublittoral \\
Ptilota plumosa (Huds.) C. Agardh & Lower sublittoral \\
\hline
\end{tabular}

able, only a few data exist on other physiological processes such as respiration and growth (Wood 1987 , Larkum \& Wood 1993, Clendennen et al. 1996, Han 1996). Therefore, this study aimed to investigate the changes in growth, photosynthetic oxygen production and respiratory oxygen consumption in Arctic macroalgae collected on Spitsbergen (Norway) and subsequently exposed to natural solar radiation or to treatments with controlled fluence rates of artifical UV radiation

\section{MATERIALS AND METHODS}

Algal material and study site. The macroalgal species studied and their occurrence in the littoral zone are listed in Table 1. The plants were collected in summer 1998 at the study site located in the Kongsfjord ( $\mathrm{Ny}$ Alesund, Spitsbergen, Norway $78^{\circ} 55.5^{\prime} \mathrm{N}, 11^{\circ} 56.0^{\prime} \mathrm{E}$ ) at the depths from $0 \mathrm{~m}$ down to $20 \mathrm{~m}$. Algal samples were collected by SCUBA diving in black bags to avoid exposure to high irradiance during transport. After sampling, the plants were kept in the laboratory in dim light and in running seawater pumped directly from the fjord.

Measurements of solar radiation. Two different sets of radiation measurements were undertaken for this study. Continuous recording of global radiation (305 to $2800 \mathrm{~nm}$ ) using a CM11-pyranometer (Kipp \& Zonen, Delft, The Netherlands) and of UV radiation (300 to $370 \mathrm{~nm}$ ) using a TUVR-photodiode detector (Eplab, Newport, Rhode Island, USA) was carried out with instruments of the Baseline Surface Radiation Network (BSRN) in cooperation with the Norsk Polar Institute in Ny-Allesund, Spitsbergen (König-Langlo \& Marx 1997). To calculate radiation of the UV and photosynthetic active radiation (PAR) wavelength range, measurements through a RG8 filter (cut-off at $695 \mathrm{~nm}$ ) (Schott, Mainz, Germany) were subtracted from the global radiation data. The radiation values

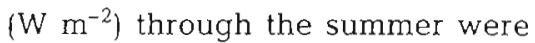
calculated 2 wk means using averaged daily irradiance values measured by the pyranometer and photodiode, respectively. The total UV (UVA+UVB) radiation was also estimated using a biological dosimeter based on a UV-sensitive bacterial spore monolayer system (VioSpor, BioSense, Bornheim, Germany). These data are expressed as 
minimal erythemal dose (MED) per day (Quintern et al. 1992, Furusawa et al. 1998). The dosimeters were exposed for $1 \mathrm{wk}$ at the surface and in the water column ( 1 and $3 \mathrm{~m}$ depth, respectively) close to the places where the experiments were conducted. In order to compare with the UV measurements from the photodiodes, dosimeter mesurements at the surface are represented by 2 wk means.

Underwater UVB radiation (280 to $320 \mathrm{~nm}$ ) was measured spectrometrically using a 32 channel quanta counting radiometer equipped with a $2 \pi$ corrected detector developed at the Alfred Wegener Institute. PAR was measured by use of an underwater spectroradiometer (Kruse, Bremerhaven, Germany). From data of both radiometers, diffuse vertical attenuation coefficients of downward irradiance $\left(K_{\mathrm{d}}\right)$ were determined using following formula (after Kirk 1994):

$$
K_{\mathrm{d}}=\ln E_{\mathrm{d}\left(z_{2}\right)} / E_{\mathrm{d}\left(z_{1}\right)} \times 1 /\left(z_{1}-z_{2}\right)
$$

where $E_{\mathrm{d}\left(z_{1}\right)}$ and $E_{\mathrm{d}\left(z_{2}\right)}$ are the respective irradiances at depths $z_{1}$ and $z_{2}$.

Growth experiments. The macroalgal species studied had to be treated differently prior to each growth experiment. Young sporophytes of 3 to $4 \mathrm{~cm}$ length of the Laminaria species and Saccorhiza dermatodea were marked with 2 punched holes ( $2 \mathrm{~mm}$ diameter) at a distance of $15 \mathrm{~mm}$ from one another in the meristematic tissue of the thallus in the longitudinal direction (Fig. 1). The length increment over time under each radiation treatment was followed by the measurement of changes in the distance between the 2 marks. Thalli of Palmaria palmata were cut $3 \mathrm{~cm}$ below the apex and their total increase in length over time was measured. In the case of Acrosiphonia penicilliformis and Fucus distichus, the growth rate was determined as the wet weight increase of young intact plants.

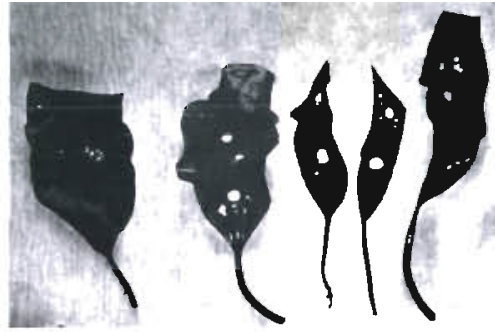

Field
PAR

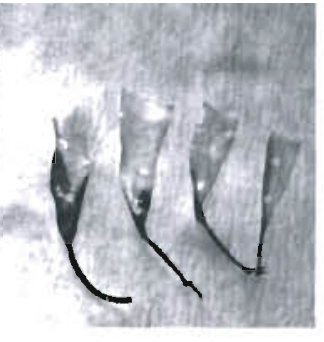

$\mathrm{PAR}+\mathrm{UV}$
Fig. 1. Laminaria saccharina. Thalli collected from the field and exposed for $1 \mathrm{wk}$ under photosynthetic active radiation (PAR) or full solar radiation. The field plant represents an untreated thallus just collected from the shore. In order to avoid self shading of the thalli in the growth chamber, they were cut in pieces of 3 to $4 \mathrm{~cm}$ length from the stipe. The initial size for the plants before exposure was the same as observed in thalli exposed to full solar radiation
In the first experimental set, plants were collected from the field and directly exposed to natural surface solar radiation. The subsamples were covered with cellulosetriacetate cut-off filters for UVB (cut off of wavelengths <320 nm; Ultraphan, Digefra GmbH, Munich, Germany) and polyester cut-off filters for UVA plus UVB (cut off of wavelengths $<395 \mathrm{~nm}$; Folex, Dreieich, Germany). The plants were then incubated outdoors in basins with running seawater. Thalli exposed to full solar radiation were rapidly and strongly affected, especially by the ultraviolet waveband as shown for the brown alga Laminaria saccharina (Fig, 1). After 1 wk exposure, only plants exposed to UV-filtered radiation survived, while under total solar radiation the thalli became totally photobleached. Therefore, all subsequent growth experiments were conducted after the photoacclimation period of 7 to $10 \mathrm{~d}$ during which the algal samples were screened with UV cut-off filters and 3 layers of neutral grey filters, each of them producing a 3 -fold reduction of the incoming light intensity. One after the other the grey filters were removed every $3 d$, which was then followed by the evaluation of the physiological fitness of the plants prior to the beginning of the growth experiment. This was done by the determination of the variable chlorophyll fluorescence of photosystem II (PSII) as an indicator for the optimum photosynthetic activity using a PAM-2000 device (Walz, Effeltrich, Germany) (Hanelt 1998). After acclimation all thalli showed $F_{v} / F_{\mathrm{m}}$ values characteristic for photosynthetically non-inhibited plants

Parallel to the surface experiments in the basins, macroalgae were exposed to natural solar radiation in the water column at depths between 1 and $5 \mathrm{~m}$ using anchored floating UV-transparent plexiglass tubes (PlexiglasXT, Röhm Darmstadt, Germany, $300 \times 110 \mathrm{~mm}$ ). Each tube was wrapped with the specific filter foils to cut off UVB and UVA+UVB.

Finally, in order to assess the growth response with respect to the depth in situ, selected thalli of Laminaria saccharina and $L$. digitata growing on the harbour sea wall were labelled by a diver at 3,6 and $9 \mathrm{~m}$. Their growth was followed over 3 wk by measuring the length of each thallus using the punched-hole method described above.

The increase in the thallus length or weight after $21 \mathrm{~d}$ of growth was used to calculate the relative growth rate, $R$, expressed as the percentage increase per day (Kain 1987, Lüning 1992):

$$
R=\left(\ln A_{21}-\ln A_{0}\right) \times 100 / 21
$$

where $A_{21}$ is the length or wet weight after 3 wk of treatment, and $A_{0}$ is the length or wet weight at the beginning.

Photosynthesis and respiration. Photosynthetic oxygen production was measured after $2 \mathrm{~h}$ (in some spe- 
cies additionally after $6 \mathrm{~h}$ exposure) to $38 \mu \mathrm{mol} \mathrm{m} \mathrm{m}^{-2} \mathrm{~s}^{-1}$ PAR provided by 1 Osram daylight fluorescence tube, $8 \mathrm{~W} \mathrm{~m} \mathrm{~m}^{-2}$ UVA (320 to $400 \mathrm{~nm}$ ) and $0.36 \mathrm{~W} \mathrm{~m}^{-2} \mathrm{UVB}$ (280 to $320 \mathrm{~nm}$ ) provided by $2 \mathrm{Q}$-Panel UVA-340 fluorescence tubes (Q-Panel Company, Cleveland, Ohio, USA). Radiation measurements were carried out with a Li-Cor LI-190-SB cosine-corrected sensor connected to a Li-Cor LI-1000 datalogger (Lambda Instruments Ltd, Lincoln, Nebraska, USA) for PAR (400 to $700 \mathrm{~nm}$ ) and with a RM-21 broadband UV radiometer (Dr Gröbel, Ettlingen, Germany) to determine UVA and UVB. $1 \mathrm{~g}$ wet weight fragments of epiphyte-free algae were incubated in UV-transparent Winkler quartz glass bottles filled with about $330 \mathrm{ml}$ of $0.45 \mu \mathrm{m}$ filtered natural seawater. 6 replicate bottles were irradiated with both types of tubes (PAR+UV treatment), and another 6 bottles were also kept covered with Ultraphan filters cutting off UVA plus UVB. After light exposure, the respiratory oxygen comsumption was estimated after following a second dark incubation period for 3 to $4 \mathrm{~h}$.

The oxygen concentration in the Winkler bottles was estimated with a temperature-compensated Clark-type electrode (WTW Oxi 323, Germany). All the experiments were carried out at 1 to $2^{\circ} \mathrm{C}$.

Statistics. Mean values and their standard deviations were calculated from the different replicates per treatment. Statistical significances of means were tested with a Model 1, 1-way ANOVA followed by a multirange test by Fisher's protected least significant difference (LSD) (Sokal \& Rohlf 1981).

\section{RESULTS}

\section{Radiation measurements}

Sun radiation measurements on Spitsbergen showed a typical seasonal pattern, with maximum values in June followed by a decrease during July and August. By the end of the summer the radiation level at the earth's surface was only one-third of the maximum recorded in the early summer both in the UV (300 to $370 \mathrm{~nm})$ and visible (370 to $695 \mathrm{~nm}$ ) range (Fig. 2a,b). The maximum averaged irradiance did not exceed $150 \mathrm{~W} \mathrm{~m}^{-2}$ in the visible part of the spectrum (Fig. 2a) and the UV radiation maximum was around $15 \mathrm{~W} \mathrm{~m}^{-2}$ (Fig. 2b). Weighted UV radiation measured in air by the biological spore-film dosimeters showed a less clear seasonal pattern. In contrast to the gradually decreasing pyranometer measurements (Fig. 2a) the dosimeter data in July drastically decreased to $50 \%$ of those in June (Fig. 2c). The differences between the 2 sets of measurements could be explained by the fact that the photodiode detector measures mainly UVA radiation, whereas the biodosimeter measures mainly the biologically effective UVB radiation. After July, the MED in air did not change until the end of the summer. The UV radiation in the water column as measured by the dosimeter followed a different pattern as observed in air (Fig. 2d). The maximum dose of UV was measured in June due to clear optical properties of the seawater just after the break-up of the ice cover on the fjord. During that period $16 \%$ of the daily MED in air was measured at $1 \mathrm{~m}$ depth and $7 \%$ at $3 \mathrm{~m}$ depth (Fig. 2d). In contrast, in July and August the lower intensity of solar radiation reaching the earth and the gradual reduction of the transparency of the seawater due to high influx of turbid melt-water from the glaciers resulted in a strong reduction of the underwater UV radiation. The averaged vertical attenuation coefficients $\left(K_{\mathrm{d}}\right)$ from the spectroradiometer measurements were $0.66 \pm 0.052$ and $0.51 \pm 0.25$ for downward UVB irradiance and for PAR, respectively, during the period of experiments (Hanelt et al. unpubl. result). As a result, at $1 \mathrm{~m}$ depth UVB was attenuated to about $51 \%$ and PAR to $60 \%$; at $3 \mathrm{~m}$ depth UVB was attenuated to $14 \%$ and PAR to $22 \%$. Thus, the water was relative opaque for solar radiation, and algae growing below $1 \mathrm{~m}$ depth were exposed to very low doses of UV radiation.
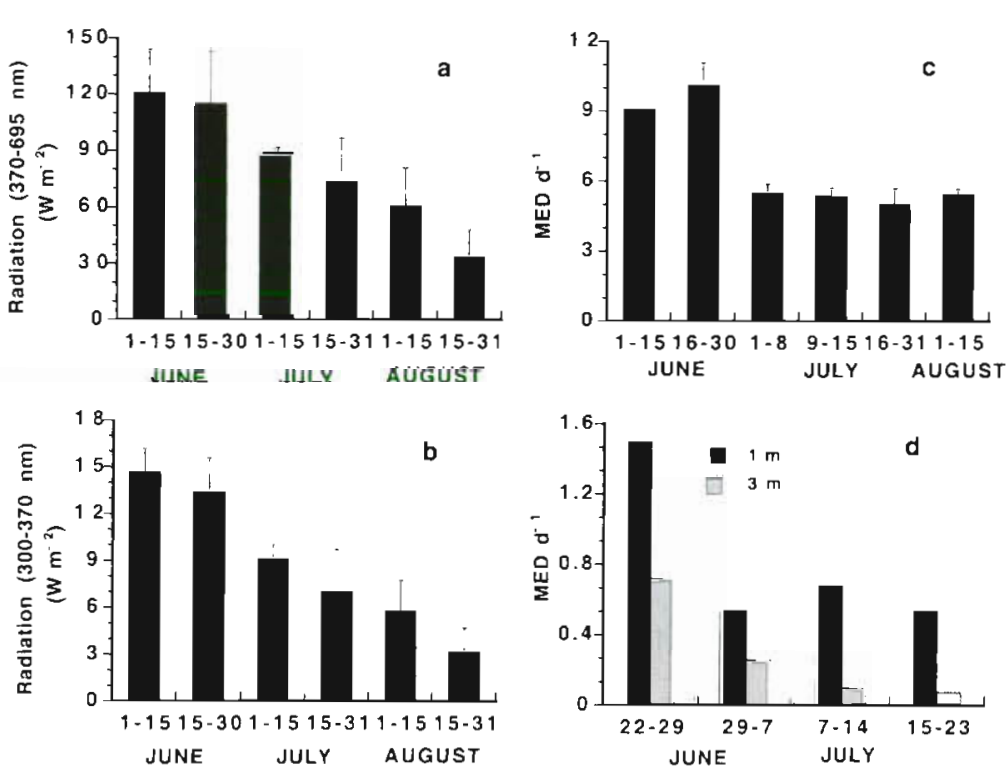

Fig. 2. Changes in solar radiation measured in air at sea level in Ny-Ålesund during summer 1998. (a) Visible (370 to $695 \mathrm{~nm}$ ) and (b) UV in the range of 300 to $370 \mathrm{~nm}$. Irradiance ( $\mathrm{W} \mathrm{m}^{-2}$ ) during the summer was calculated in an interval of $2 \mathrm{wk}$ as the average of the daily data. Total UV radiation measured with a biological dosimeter (VioSpor) (c) in air at sea level and (d) in the water column at 1 and $3 \mathrm{~m}$ depth. Data are expressed as minimal erythemal dose (MED) per day 

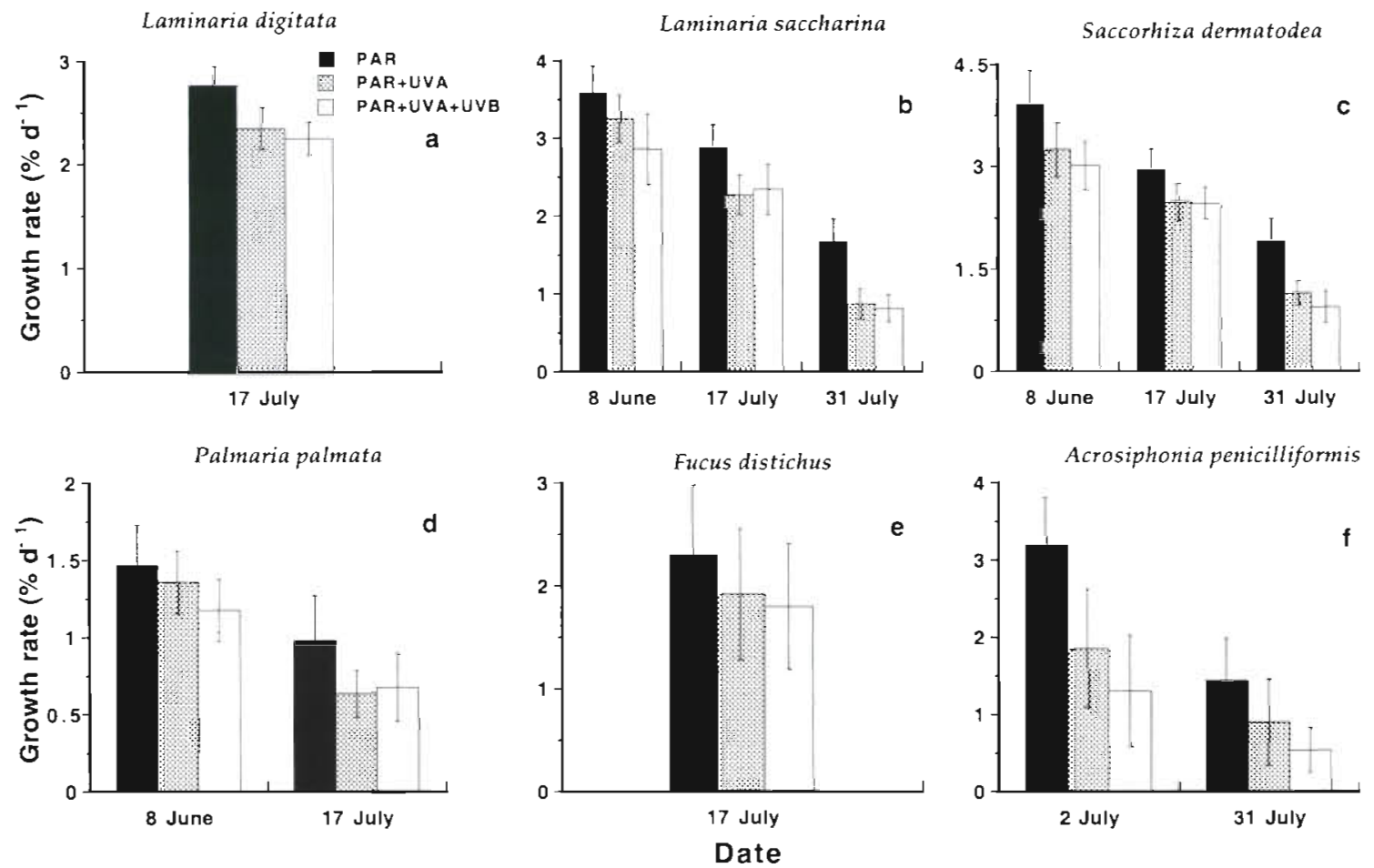

Fig. 3. Growth rate of selected macroalgal species exposed to solar radiation in basins at sea level during summer 1998. Experiments were initiated at each date given and subsequently run for 3 wk. Plants were exposed to filtered solar UV radiation (PAR $>400 \mathrm{~nm}$ ), filtered UVB radiation (PAR+UVA $>320 \mathrm{~nm}$ ) and unfiltered solar radiation (PAR+UVA+UVB). Vertical bars indicate the standard deviation of 16 replicates per treatment

\section{Field growth measurements}

Solar radiation affects the growth activity of macroalgae in surface waters in summer (Fig. 3). For all radiation conditions, the highest growth rates in all the species studied were always found in June, followed by a gradual decrease in July and August. In spite of the positive correlation between the growth activity of the algae and solar radiation reaching the earth's surface, this decrease in the growth rate may be a result of the seasonal growth pattern of the plants as discussed below. The irradiance impinging on the water surface at the end of the summer is still saturating for photosynthesis as observed in some species (data not shown)

All species were partially inhibited by UV radiation at the sea surface (Fig. 3). While Laminaria digitata which inhabits the upper sublittoral exhibited a small decrease in growth rate in both UV treatments, no significant difference between PAR+UVA and full solar radiation could be observed ( $p>0.05,1$-way ANOVA) (Fig 3a). Only 1 outdoor experiment could be performed with this species due to strong ice cover near the collection site at the beginning of the summer. The growth of $L$. saccharina was significantly affected by both the PAR+UVA and the PAR+UVA+UVB treat- ments ( $p<0.05,1$-way ANOVA) during June radiation maximum (Fig. 3a). However, in both experiments performed in mid-and late July no differences between the PAR+UVA and the ambient radiation solar exposure (PAR+UVA+UVB) could be estimated, while the difference in growth rate between PAR and PAR+UV was significant ( $p<0.05,1$-way ANOVA). Growth of Saccorhiza dermatodea and Palmaria palmata was also inhibited by UV radiation compared to the PAR treatment and this could be observed throughout the summer as observed in $L$. saccharina (Fig. $3 b$ to d). In the case of the intertidal brown alga Fucus distichus, exposure to full solar radiation did not significantly affect the growth rate ( $p>0.05,1$-way ANOVA) (Fig. 3e). In contrast, the green alga Acrosiphonia penicilliformis, which grows very close to $F$. distichus, was strongly influenced by UV radiation (Fig. 3f). While the UVA treatment inhibited the growth rate by $40 \%$ of the PAR, UVA+UVB led to an even stronger response, resulting in a $60 \%$ reduction of the growth activity $(\mathrm{p}<0.05,1$-way ANOVA)

Growth of the 3 Laminaria species exposed at the different water depths was affected by the radiation penetrating into the sea $(p<0.05,1$-way ANOVA) (Fig. $4 \mathrm{a}$ to $\mathrm{C}$ ). However, at the chosen depths between 1 and $3 \mathrm{~m}$ no significant effect of UV radiation on this 

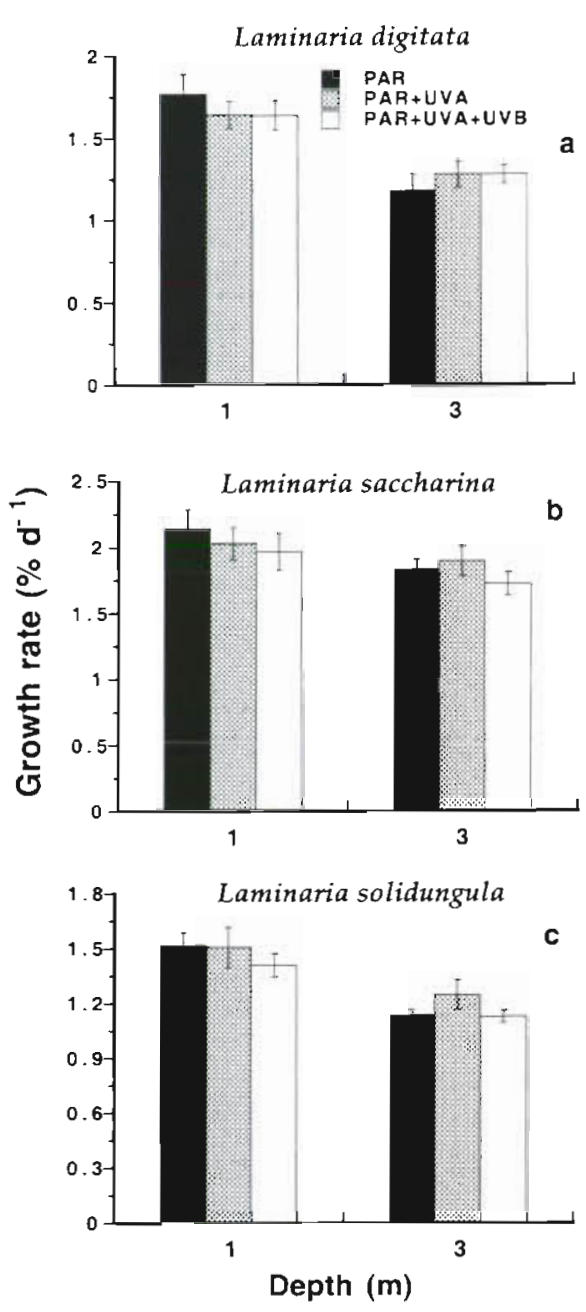

Fig. 4. Growth rate of 3 different Laminaria species in incubators exposed to various radiation treatments at different depths in the water column. Vertical bars indicate the standard deviation of 16 replicates per treatment. Differences were significant between the 2 depth treatments (at $p=0.05$, $\mathrm{n}=16$ ), but not among the different radiation treatments at each depth. For radiation treatments see Fig. 3

physiological process could be determined ( $p>0.05$, 1 -way ANOVA) due to the strong attenuation of underwater UVA+UVB radiation $\left(K_{\mathrm{d}}\right.$ for UVB $=0.66$ and for UVA $=0.62$; Fig. $2 \mathrm{~d}$ ). However, there was a correlation between growth rate and depth. While the maximum growth rate of $L$. digitata decreased by $35 \%$ at $3 \mathrm{~m}$ compared to $1 \mathrm{~m}$, the growth rates of $L$. saccharina and L. solidungula declined by 15 and $25 \%$, respectively, at $5 \mathrm{~m}$ compared to $3 \mathrm{~m}$ (Fig. $4 \mathrm{a}$ to $\mathrm{c}$ ).

Similar results were obtained in situ. Growth of Laminaria saccharina and L. digitata was studied at 3,6 and $9 \mathrm{~m}$ depth (Fig. 5), and a linear correlation between growth rate and depth could be demonstrated for both species. While for $L$. saccharina a $6.8 \%$ decrease in growth rate per meter increase of depth

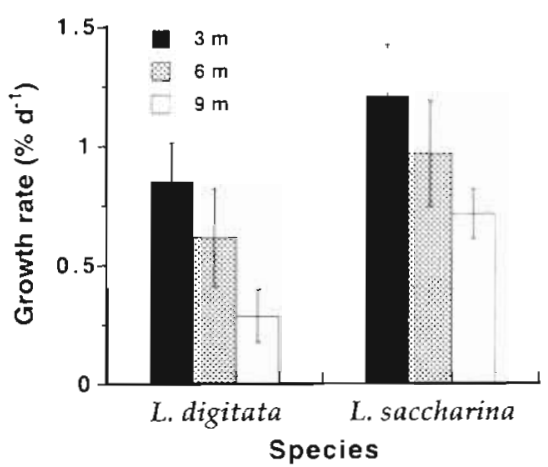

Fig. 5. In situ growth rates of Laminaria digitata and $L$. saccharina at different depths at the harbour sea wall. Vertical bars indicate the standard deviation of 7 replicates per treatment

was observed, that of $L$. digitata decreased by $11 \%$. This corresponded with an average $K_{\mathrm{d}}$ of PAR of about $0.66 \pm 0.052$ in the water column

\section{Photosynthetic and respiratory performance}

In most macroalgal species studied photosynthetic oxygen production was strongly affected after exposure to artificial PAR+UV radiation compared to the PAR treatment (Table 2). Only Fucus distichus, Monostroma arcticum and Laminaria digitata, all from the eulittoral and upper sublittoral zone, did not show any significant decrease in photosynthesis. As observed with growth rate, the photosynthetic activity of the other eulittoral species, Acrosiphonia penicilliformis, was also reduced by $40 \%$ at the UV level compared with PAR. In contrast, in most plants from the upper and lower sublittoral zone photosynthesis was strongly affected by $U V$, resulting in rates of 6 to $61 \%$ in respect to PAR treatments ( $\mathrm{p}<0.05,1$-way ANOVA). The absolute values for photosynthetic oxygen production among all macroalgal species studied ranged from 2.8 to $20.6 \mu \mathrm{mol} \mathrm{O} \mathrm{O}_{2} \mathrm{~g}$ wet weight (fresh weight [FW]) $\mathrm{h}^{-1}$

Increasing the exposure time of UV radiation in some brown algal species from 2 to $6 \mathrm{~h}$ was accompanied with even stronger inhibition of photosynthesis (Fig. 6). While Fucus distichus was again almost tolerant even in prolonged UV treatments, the 3 laminareans Laminaria digitata, L. saccharina and L. solidungula showed a severe decrease in photosynthesis after $6 \mathrm{~h}$ of exposure. In the case of $L$. saccharina and $L$. solidungula the photosynthetic oxygen production was almost completely inhibited by the end of the experiment, although the respiratiory activity was still observed (Fig. 6).

In contrast to the sensitive photosynthesis after exposure to UV, respiration was generally not inhibited 
Table 2. Effect of ultraviolet radiation on the photosynthetic and respiration rates of Arctic macroalgae collected in the Kongsfjord, Spitsbergen, Norway. Plants were exposed for $2 \mathrm{~h}$ to a combination of artificial radiation lamps giving $30 \mu \mathrm{mol} \mathrm{m} \mathrm{m}^{-2} \mathrm{~s}^{-1} \mathrm{PAR}$ and $7 \mathrm{~W} \mathrm{~m}^{-2}$ UVA plus $0.7 \mathrm{~W} \mathrm{~m}^{-2} \mathrm{UVB}$. The PAR treatment was conducted by filtering the total UV radiation by means of $400 \mathrm{~nm}$ cut-off filters. All data are given as $\mu \mathrm{mol} \mathrm{O} \mathrm{K}_{2} \mathrm{~kg}^{-1}$ fresh weight $\mathrm{h}^{-1}$ and represent the mean value of 6 replicates ( $\mathrm{SD}$ ). The percentage of photosynthetic rate under PAR+UV with respect to PAR is also presented. "Significant differences between both radiation treatments (at $p=0.05, n=6$ ) as determined in a Model 1, 1-way ANOVA followed by a multi-range test by Fisher's protected least significant difference (LSD)

\begin{tabular}{|c|c|c|c|c|c|}
\hline Species & $\begin{array}{c}\text { Photosynthesis, } \\
2 \text { h PAR }\end{array}$ & $\begin{array}{l}\text { Photosynthesis, } \\
2 \text { h PAR+UV }\end{array}$ & $\begin{array}{c}\text { Difference } \\
\text { (\% of PAR treatment) }\end{array}$ & $\begin{array}{l}\text { Respiration, } \\
2 \text { h PAR }\end{array}$ & $\begin{array}{l}\text { Respiration, } \\
2 \text { h PAR+UV }\end{array}$ \\
\hline \multicolumn{6}{|l|}{ Chlorophyta } \\
\hline Acrosiphonia penicilliformis & $7.31 \pm 0.97$ & $4.28 \pm 0.50^{\circ}$ & 58.5 & $1.78 \pm 0.25$ & $1.56 \pm 0.34$ \\
\hline Monostroma arcticum & $20.56 \pm 8.93$ & $16.68 \pm 7.34$ & 81.1 & $5.13 \pm 0.66$ & $6.72 \pm 0.97^{\circ}$ \\
\hline \multicolumn{6}{|l|}{ Phaeophyta } \\
\hline Desmarestia aculeata & $11.63 \pm 2.31$ & $0.66 \pm 0.45^{\circ}$ & 5.7 & $2.75 \pm 0.56$ & $3.97 \pm 1.03^{\circ}$ \\
\hline Fucus distichus & $4.13 \pm 1.41$ & $4.28 \pm 0.88$ & 103.6 & $0.88 \pm 0.16$ & $1.00 \pm 0.02$ \\
\hline Laminaria digitata & $2.78 \pm 0.50$ & $2.06 \pm 0.50$ & 74.1 & $0.66 \pm 0.09$ & $0.78 \pm 0.09$ \\
\hline Laminaria saccharina & $6.13+0.88$ & $1.53 \pm 0.44^{\circ}$ & 25.0 & $1.00 \pm 0.06$ & $1.19 \pm 0.28$ \\
\hline Laminaria solidungula & $4.84 \pm 0.97$ & $1.22 \pm 0.44^{\circ}$ & 25.2 & $0.78 \pm 0.16$ & $0.91 \pm 0.16$ \\
\hline Saccorhiza dermatodea & $3.56 \pm 1.00$ & $0.84^{ \pm} \pm 0.47^{\circ}$ & 23.6 & $0.63 \pm 0.19$ & $0.72 \pm 0.34$ \\
\hline \multicolumn{6}{|l|}{ Rhodophyta } \\
\hline Devaleraea ramentacea & $8.13 \pm 0.44$ & $3.25 \pm 0.56^{\circ}$ & 40.0 & $0.97 \pm 0.19$ & $0.90 \pm 0.31$ \\
\hline Odonthalia dentata & $5.47 \pm 1.06$ & $1.41 \pm 0.41^{\circ}$ & 25.8 & $2.75 \pm 0.28$ & $2.47 \pm 0.22$ \\
\hline Palmaria palmata & $9.31 \pm 1.19$ & $3.38 \pm 0.44^{\circ}$ & 36.3 & $1.28 \pm 0.16$ & $1.16 \pm 0.16$ \\
\hline Phycodrys rubens & $5.78 \pm 0.91$ & $3.00 \pm 1.16^{\circ}$ & 51.9 & $1.53 \pm 0.34$ & $1.84 \pm 0.22$ \\
\hline Phyllophora truncata & $6.03 \pm 1.09$ & $4.69 \pm 0.50^{\circ}$ & 77.8 & $0.72 \pm 0.16$ & $0.63 \pm 0.16$ \\
\hline Ptilota plumosa & $5.31 \pm 0.72$ & $3.25 \pm 0.75^{\circ}$ & 61.2 & $0.84 \pm 0.22$ & $0.75 \pm 0.13$ \\
\hline
\end{tabular}

(Table 2). With the exception of Desmarestia aculeata and Monostroma arcticum, all plants showed almost unchanged respiratory rates after $2 \mathrm{~h}$ UV treatment. In a few species tested, an increase of the exposure time to $6 \mathrm{~h}$ UV radiation also did not affect this metabolic

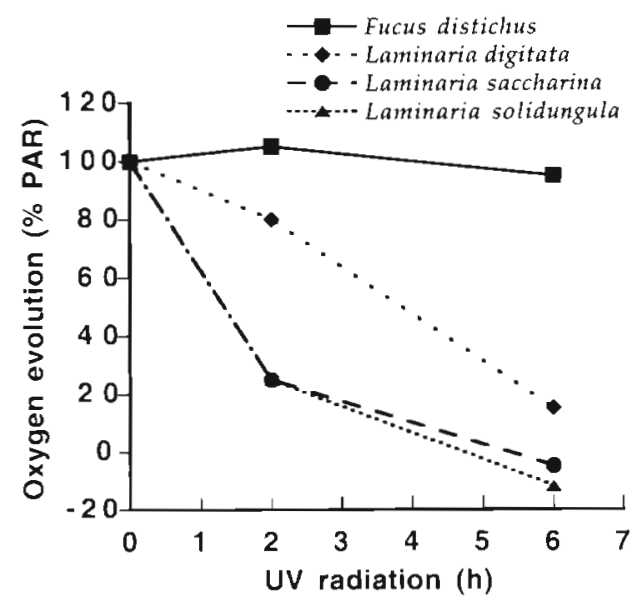

Fig. 6. Oxygen evolution (production or consumption) in Arctic brown macroalgae after 2 and 6 h exposure to artificial $30 \mu \mathrm{mol} \mathrm{m} \mathrm{m}^{-2} \mathrm{~s}^{-1}$ photosynthetic active radiation (PAR) and to

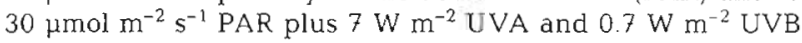
$(\mathrm{PAR}+\mathrm{UV})$. The oxygen production under PAR of each macroalgal species was set to $100 \%$ and compared to the respective activity under PAR+UV. Standard deviation was less than $15 \%$ process (data not shown). However, in D. aculeata and $M$. arcticum a significant stimulation of respiration by 44 and $31 \%$, respectively, was determined after $2 \mathrm{~h} \mathrm{UV}$ treatment ( $p<0.05,1$-way ANOVA) (Table 2$)$. The absolute values for respiratory oxygen consumption among all macroalgal species studied ranged from 0.4 to $5.9 \mathrm{\mu mol} \mathrm{O}_{2} \mathrm{~g}$ wet weight (FW) $\mathrm{h}^{-1}$.

\section{DISCUSSION}

Due to the latitude and the rapid changes of weather conditions during the summer season, solar radiation at the surface is relatively low and subjected to marked fluctuations. Maximum averaged radiation in the visible part of the solar spectrum (370 to $695 \mathrm{~nm}$ ) during the experimental period was measured in June and did not exceed a daily mean value of $150 \mathrm{~W} \mathrm{~m}^{-2}, 15 \mathrm{~W} \mathrm{~m}$-2 for UV radiation in the range of 300 to $370 \mathrm{~nm}$ and $0.273 \mathrm{~W} \mathrm{~m}^{-2}$ for solely UVB. In a recent study at the same location seasonal maximum values of $250 \mathrm{~W} \mathrm{~m}^{-2}$ for PAR, $19 \mathrm{~W} \mathrm{~m}^{-2}$ for UVA and of $1.1 \mathrm{~W} \mathrm{~m}^{-2}$ for UVB were reported in mid-June on a sunny day (Bischof et al. 1998a). These irradiances are still low compared with maximum radiation values at lower latitudes. While measurements with a spectroradiometer oscillate at midday in summer on Helgoland (North Sea) between 280 and $380 \mathrm{~W} \mathrm{~m}^{-2}$, UVA between 30 and 
$40 \mathrm{~W} \mathrm{~m}^{-2}$, and UVB between 1.7 and $2.2 \mathrm{~W} \mathrm{~m}^{-2}$ (Dring et al. 1996a), in southern Spain PAR, UVA and UVB can reach values of 450,50 and up to $3 \mathrm{~W} \mathrm{~m}^{-2}$, respectively (Figueroa et al. 1997).

The penetration of solar radiation into the water column on Spitsbergen also experiences drastic and rapid changes during the summer season. Due to a later spring in 1998, the water in the studied fjord was covered with a $1 \mathrm{~m}$ thick ice layer that did not disappear until 22 June. Although this month coincided with the highest water transparency for PAR and UV the ice cover reduced downwelling radiation by about $90 \%$ (Hanelt et al. unpubl. result). Usually, the ice cover disappears on Spitsbergen in late April/early May, and at this time the water in the Kongsfjord is clear and UVB radiation penetrates down to approximately $10 \mathrm{~m}$ (Bischof et al. 1998a). However, after the sea-ice breakup in 1998 there was a high input of turbid water due to melting of snow and calving of glaciers also causing a high influx of sediment into the water. Under these conditions the water transparency was very low and a large fraction of the impinging UV radiation was attenuated in the upper few metres of the water column (Fig. 2d).

The algal growth at the water surface confirms a general tendency toward an inhibitory effect of UV radiation. Transplantation experiments from protected to stressed environmental conditions are important to better understand the acclimation potential and the distribution patterns of these plants on the shore. Using such an experimental design, area- and weight-based growth rates in Ulva expansa were reported to be enhanced by excluding UV (Grobe \& Murphy 1994). Growth of deep-water species was UV sensitive compared to shallow-water plants. Except for intertidal Fucus distichus, growth of all other studied species was affected by UVA and UVB. These growth data are in good agreement with the in vivo chlorophyll fluorescence measurements, which showed decreasing photosynthetic activity under UV in the same species (Hanelt et al. 1997). In the case of the other intertidal alga Acrosiphonia penicilliformis, growth rate was strongly inhibited under total UV, as well as under PAR+UVA. In both species, the adaptation strategy to survive under exposed and stressed conditions in the intertidal zone is different. Morphology, i.e. a thicker thallus, such as that in the kelp species Fucus or Laminaria, does better protect against high solar radiation. In such macroalgae the fluence rate of harmful radiation decreases strongly towards the inner cell layers (Dring et al. 1996b). Changes of chloroplast distribution within the cortex cell is another mechanism which decreases light absorbance especially in the outer cortex layers due to an increased sieve mechanism. The occurrence of a light-induced chloroplast displacement in seaweeds was shown by Nultsch \& Pfau (1979). Later, Hanelt \& Nultsch (1991) demonstrated that it is predominantly an effect due to protection from light. Growth and photosynthesis of $A$. penicilliformis was sensitive to UV radiation despite the high position of this species on the shore. This can be explained by its thallus structure with interwoven fell-like filaments at the base and slender separate filaments at the periphery of the thallus. While only the latter apical regions of the alga are exposed to strong light the basal cells are well protected due to self shading. In the field yellow-coloured tips were often observed, indicating a lack of chlorophyll as a consequence of photobleaching of the apical parts, along with dark-green pigmented healthy and non-light-stressed basal parts (data not shown).

Deep-water species transplanted to the surface showed different UV sensitivities (Fig. 3). With the exception of Laminaria saccharina and Palmaria palmata in the experiments at the beginning of the summer, the growth of all other species was already partially inhibited by UVA (320 to $400 \mathrm{~nm}$ ). Compared to full solar radiation the inhibition was not significantly different. A reason could be the low UVB irradiance reaching the sea surface which therefore did not amply signify the inhibitory effect of UVA. Among the laminarean species, L. digitata grows in the upper part of the shore and showed a growth rate rather indifferent to UV compared to the strongly affected L. saccharina inhabiting deeper zones. These results confirm observations on the laminarean species distributed on the island of Helgoland (Dring et al. 1996b). Those authors showed that growth and photosynthesis of sporophytes of $L$. saccharina were also more sensitive to UV than higher located L. digitata and L. hyperborea. UV radiation penetrating into the water column may effectively control the upper algal distribution limit. As a consequence, $L$. saccharina shows a higher growth rate than L. digitata (Figs. $4 \& 5$ ) at the same depth if the UV irradiation becomes too low to be harmful. Besides UV, penetrating PAR also suppress the growth of algae (Fig. 5). Thus, on Spitsbergen, in spite of incident irradiance, levels are low in comparison with other latitudes, and when the water transparency allows good UV radiation penetration, UV radiation can be a controlling factor in communities since this is an evident stress source for most macroalgae.

Although the effect of other physical parameters on algal communities in the Kongsfjord has still to be evaluated it is obvious from the data that solar radiation is one of the key factors controlling algal growth. The decrease in the growth rate observed between June and August in almost all species was directly correlated with the changes in the total solar irradiance. Light and other abiotic factors have been described to directly affect the algal distribution in Antarctic macro- 
algal communities (Drew \& Hastings 1992, Klöser et al. 1993, Gómez et al. 1997). However, the seasonal growth pattern observed may not just be determined by the intensity of solar radiation. The seasonal course of daylength can also determine seasonality of growth and other physiological processes (Gómez et al. 1995, 1997. Weykam \& Wiencke 1996, Gómez \& Wiencke 1997). This is the case of the so-called 'season anticipators', where seasonal development is based on photoperiodism or circannual rhythms (Lüning 1986, 1988, 1991, 1994, Lüning \& Dieck 1989). The annual maximum of the growth rate of Laminaria saccharina on the Alaska Arctic coast is between late April and late July (Dunton 1985). In contrast, L. solidungula from the same place completed most of its annual growth in darkness during late winter and spring (Dunton \& Schell 1986, Dunton 1990). The growth strategy of both species differs in the capability for storage of carbon reserve carbohydrates and their later remobilisation (Dunton 1985, Dunton \& Schell 1986, Henley \& Dunton 1995, 1997). In the case of the Arctic Laminariales a drastic decrease in the growth rate after spring coincides with an increase in the photosynthetic activity during the strong light period in summer in order to accumulate new carbon reserves to produce new frond tissue during ice-cover periods (Dunton 1985, 1990).

In this study, the higher early summer growth rates of $L$. saccharina, Saccorhiza dermatodea and Palmaria palmata occur in June and the later decrease may also be a consequence of this seasonal change of physiological activities. In this respect, the higher inhibitory effect of UV on growth at the end of the summer, observed in L. saccharina and $S$. dermatodea, may be due to the change from high growth activity to high photosynthetic performance. Therefore, the analysis of the UV effects on photosynthesis is crucial. Most species investigated already showed strong inhibition in photosynthetic oxygen production after $2 \mathrm{~h}$ exposure to artificial UV radiation (Figs. 3 \& 4). The UV irradiances chosen in this study were lower than those occurring in nature. However, it should be considered that under the artifical light sources PAR was much lower than under natural conditions. Nevertheless, the plants were more or less affected by the relatively low UV irradiances. Photosynthesis of macroalgae generally seems to be a major physiological target for UV radiation (Franklin \& Forster 1997, Häder \& Figueroa 1997, Häder et al. 1998). This was also demonstrated by the previous studies using the in vivo chlorophyll fluorescence of PSII (Herrmann et al. 1995, Hanelt et al. 1997. Bischof et al. 1998a,b, Häder et al. 1998). Although in macroalgal species weak correlations were sometimes demonstrated between fluorescence parameters and oxygen data (Hanelt \& Nultsch 1995), the oxygen results of the present investigation are in good agreement with the earlier reports on polar macroalgae using the fluorescence technique (Hanelt et al. 1997, Bischof et al. 1998a,b). The latter authors showed that the intertidal Fucus distichus was generally much more resistant to UV compared to sublittoral species such as $L$. saccharina.

A decrease of photosynthetic activity under UV radiation is the result of various biomolecules such as nucleic acids, lipids and proteins being damaged due to absorption of the high energetic quanta of the UV waveband. As a consequence the ability of thylakoids to maintain their electrochemical gradient can decrease (Strid et al. 1996), and the degradation of essential molecules such as the $D_{1}$ protein (Greenberg et al. 1989), the water-splitting complex (Vass et al. 1996) or ribulose 1,5-bisphosphate carboxilase-oxigenase (Strid et al. 1990) can increase. However, macroalgae have developed physiological processes such as dynamic photoinhibition to regulate their photosynthetic activity to adapt to and be protected against temporary excessive radiation (Hanelt 1998). This author demonstrated that the capability of dynamic photoinhibition and especially the rate of recovery in macroalgae after offset of radiation stress is strongly related to their depth distribution on the shore. The degree of inhibition of photosynthetic oxygen production under UV treatment can be correlated to the depth zonation as well (Table 2). Fucus distichus was almost insensitive to prolonged periods of UV exposure, as reflected in growth response. In contrast, the 3 Laminaria species tested showed much less resistant photosynthesis. However, while $L$. digitata, which grows in the intertidal to higher sublittoral zone, showed a strong but incomplete decrease in photosynthetic oxygen production only after $6 \mathrm{~h}$ of UV exposure, $L$. saccharina and $L$. solidungula, from the deeper sublittoral zone, were fully inhibited and exhibited low respiratory activity instead (Table 2).

Exposure to UV radiation did not affect respiratory oxygen consumption in most macroalgal species studied (Table 2). This is consistent with results on various green, brown and red macroalgae from warm, temperate waters in Australia, which exhibited insensitive respiration under UV treatment as well (Larkum \& Wood 1993). Similarly, UV radiation did not produce any significant change in the rate of dark respiration in the giant kelp Macrocystis pyrifera from Californian waters (Clendennen et al. 1996). The data available from the few publications on macroalgae and those presented here clearly indicate that respiration is much more resistant to UV stress compared to photosynthesis. In the case of Desmarestia aculeata photosynthesis was most severely inhibited under UV, and hence it may be speculated that a stimulation in respiration may be essential to guarantee the maintainance of basal metabolism. 
Ecophysiological studies on other environmental stresses such as salinity changes and desiccation revealed that photosynthesis is strongly inhibited in macroalgae but respiration is not (Wiltens et al. 1978, Kirst 1990). In the case of osmotic stress the different response pattern between photosynthesis and respiration can be explained by ultrastructural changes in the thylakoid arrangements of the chloroplasts (Wiencke 1982), while mitochondrial fine structure is much less affected (Kirst 1990). In addition, while mitochondria in macroalgae are numerous, small and often localized in the inner parts of the cells opposite to the thallus surface, the single or few relatively large chloroplasts occupy the area adjacent to the outer cell walls. Moreover, photosynthetic tissues are always localized at the thallus surface whereas the mitochondria-rich medulla is protected within the thallus. However, the question of whether structural, physiological or biochemical features are responsible for the obvious differences in the response pattern between both organelles under UV radiation has to be investigated in future studies. In conclusion, although respiration in Arctic macroalgae is not influenced by UV radiation the conspicuous inhibition of the photosynthetic activity is finally reflected in the growth rate as the integrating process for all physiological and morphological responses in the plant.

Acknowledgements. The authors would like to thank Thomas Sawall and Kai Bischof for collecting the plant material and for logistic help, Dr Ivan Gómez for his help in the statistical analysis of the samples, and the Ny-Ålesund International Research and Monitoring Facility for their support. This project was financially supported by the European Union (Project ENV4-CT96-0188 (DG 12) - UV/marine macrophytes). J.A. is grateful to the Ministerio de Educación y Cultura of Spain and the Alexander von Humboldt Foundation for supporting his research. This is publication no. 1655 of the Alfred Wegener Institute for Polar and Marine Research, Bremerhaven.

\section{LITERATURE CITED}

Bischof K, Hanelt D, Wiencke C (1998a) UV-radiation can affect depth-zonation of Antarctic macroalgae. Mar Biol 131:597-605

Bischof K, Hanelt D, Tüg H, Karsten U, Brouwer PEM, Wiencke $C$ (1998b) Acclimation of brown algal photosynthesis to ultraviolet radiation in Arctic coastal waters (Spitsbergen, Norway). Polar Biol 20:388-395

Boelen P, Obernosterer I, Vink AA, Buma AGJ (1999) Attenuation of biologically effective UV radiation in tropical atlantic waters measured with a biochemical DNA dosimeter. Photochem Photobiol 69:34-40

Buma AGJ, van Hannen EJ, Roza L, Veldhuis MJW, Gieskes WWC (1995) Monitoring ultraviolet-B-induced DNA damage in individual diatom cells by immuno-fluorescent thymine dimer detection. J Phycol 31:314-321

Buma AGJ, Engelen AH, Gieskes WWC (1997) Wavelengthdependent induction of thymine dimers and growth rate reduction in the marine diatom Cyclotella sp. exposed to ultraviolet radiation. Mar Ecol Prog Ser 153:91-97

Clendennen SK, Zimmerman RC, Powers DA, Alberte RS (1996) Photosynthetic response of the giant kelp Macrocystis pyrifera (Phaeophyceae) to ultraviolet radiation. J Phycol 32:614-620

Davidson AT, Marchant HJ, de la Mare WK (1996) Natural UVB exposure changes the species composition of Antarctic phytoplankton in mixed culture. Aquat Microb Ecol 10: 299-305

Drew KH, Hastings RM (1992) A year-round ecophysiological study of Himantothallus grandifolius (Desmarestiales, Phaeophyta) at Signy Island, Antarctica. Phycologia 31. 262-277

Dring MJ, Wagner A, Boeskov J, Lüning K (1996a) Sensitivity of intertidal and subtidal red algae to UVA and UVB, as monitored by chlorophyll fluorescence measurements: influence of collection depth and season, and length of irradiation. Eur J Phycol 31:293-302

Dring MJ, Makarov V, Schoschina E, Lorenz M, Lüning K (1996b) Influence of ultraviolet-radiation on chlorophyll fluorescence and growth in different life-history of three species of Laminaria (Phaeophyta). Mar Biol 126: $183-191$

Dunton KH (1985) Growth of dark-exposed Laminaria saccharina (L.) Lamour. and Laminaria solidungula J. Ag. (Laminariales: Phaeophyta) in the Alaskan Beaufort Sea. J Exp Mar Biol Ecol 94:181-189

Dunton KH (1990) Growth and production in Laminaria solidungula: relation to continuous underwater light levels in the Alaskan High Arctic. Mar Biol 106:297-304

Dunton KH, Schell DM (1986) Seasonal carbon budget and growth of Laminaria solidungula in the Alaskan High Arctic. Mar Ecol Prog Ser 31:57-66

Figueroa FL, Salles S, Aguilera J, Jimenez C, Mercado J, Viñegla B, Flores A, Altamirano M (1997) Effects of solar radiation on photoinhibition and pigmentation in the red alga Porphyra leucosticta. Mar Ecol Prog Ser 151:81-90

Forster RM, Lüning K (1996) Photosynthetic response of Laminaria digitata to ultraviolet $\mathrm{A}$ and $\mathrm{B}$ radiation. Sci Mar 60(Suppl 1):65-71

Franklin LA, Forster RM (1997) The changing irradiance environment: consequences for marine macrophyte physiology, productivity and ecology. Eur J Phycol 32:207-232

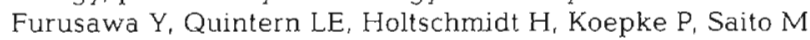
(1998) Determination of erythema-effective solar radiation in Japan and Germany with a spore monolayer film optimized for the detection of UVB and UVA-results of a field campaign. Appl Microbiol Biotechnol 50:597-603

Gómez I, Wiencke C (1997) Seasonal growth and photosynthetic performance of the Antarctic macroalga Desmarestia menziesii (Phaeophyceae) cultivated under fluctuating antarctic daylengths. Bot Acta 110:25-31

Gómez I, Wiencke C, Weykam G (1995) Seasonal photosynthetic characteristics of Ascoseira mirabilis (Ascoseriales. Phaeophyceae) from King George Island, Antarctica. Mar Biol 123:167-172

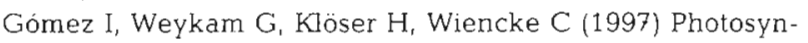
thetic light requirements, metabolic carbon balance and zonation of sublittoral macroalgae from King George Island (Antarctica). Mar Ecol Prog Ser 148:281-293

Greenberg BM, Gaba V, Canaani O, Malkin S, Matoo AK, Edelmann M (1989) Separate photosensitisers mediate degradation of the $32-\mathrm{kDa}$ photosystem II reaction centre protein in the visible and UV spectral regions. Proc Natl Acad Sci USA 86:6617-6620

Grobe CW, Murphy TM (1994) Inhibition of growth of Ulva 
expansa (Chlorophyta) by ultraviolet-B radiation. J Phycol 30:783-790

Häder DP, Figueroa FL (1997) Photoecophysiology of marine macroalgae. Photochem Photobiol 66:1-14

Häder DP, Kumar HD, Smith RC, Worrest RC (1998) Effects on aquatic ecosystems. J Photochem Photobiol 46:53-68

Han T (1996) Effect of ultraviolet-B radiation on Ulva pertusa Kjellman (Chlorophyta) I. Growth and pigment content. Kor J Phycol 11:155-159

Hanelt D (1998) Capability of dynamic photoinhibition in Arctic macroalgae is related to their depth distribution. Mar Biol 131:361-369

Hanelt D. Nultsch W (1991) The role of chromatophore arrangement in protecting the chromatophores of the brown alga Dictyota dichotoma against photodamage. J Plant Physiol 138:470-475

Hanelt D, Nultsch W (1995) Field studies on photoinhibition show non-correlations between oxygen and fluorescence measurements in the Arctic red alga Palmaria palmata. J Plant Physiol 145:31-38

Hanelt D, Wiencke $C$, Nultsch W (1997) Influence of UV radiation on the photosynthesis of Arctic macroalgae in the field. J Photochem Photobiol 30:179-187

Henley WJ, Dunton KH (1995) A seasonal comparison of carbon, nitrogen, and pigment content in Laminaria solidungula and $L$. saccharina (Phaeophyta) in the Alaskan Arctic. J Phycol 31:325-331

Henley WJ, Dunton KH (1997) Effects of nitrogen supply and continuous darkness on growth and photosynthesis of the arctic kelp Laminaria solidungula. Limnol Oceanogr 42: $209-216$

Herrmann H, Ghetti F, Scheuerlein R, Häder DP (1995) Photosynthetic oxygen and fluorescence measurements in Ulva laetevirens affected by solar irradiation. J Plant Physiol 145:221-227

Jokiel PL (1980) Solar radiation and coral reef epifauna. Science 207:1069-1071

Kain JM (1987) Seasonal growth and photoinhibition in Plocamium cartilagineum (Rhodophyta) of the Isle of Man. Phycologia 26:88-99

Karentz D, McEuen FS, Land MC, Dunlap WC (1991) Survey of mycosporine-like amino acid compounds in Antarctic organisms: potential protection from ultraviolet exposure. Mar Biol 108:157-166

Kirk JTO (1994) Light and photosynthesis in aquatic ecosystems, 2nd edn. Cambridge University Press, Cambridge

Kirst GO (1990) Salinity tolerance of eukaryotic marine algae. Annu Rev Plant Physiol Plant Mol Biol 41:21-53

Klekowski RZ, Weslawski JM (1995) Atlas of the marine flora of southern Spitsbergen. Institute of Oceanography, Gdansk

Klöser H, Ferreyra G, Schloss Y, Mercuri G, Laturnus F, Curtosi A (1993) Seasonal variation of algal growth conditions in sheltered Antarctic bays: the example of Potter Cove (King George Island, South Shetlands). J Mar Syst 4:289-301

König-Langlo G, Marx B (1997) The meteorological information system at the Alfred Wegener Institute. In: Lautenschlager $M$, Reinke $M$ (eds) Climate and environmental database system. Kluwer Academic Publisher, Norvell, MA, p 27-36

Larkum AWD, Wood WF (1993) The effect of UVB radiation

Editorial responsibility: Otto Kinne (Editor),

Oldendorf/Luhe, Germany on photosynthesis and respiration of phytoplankton, benthic macroalgae and seagrasses. Photosynth Res $36: 17-23$

Lüning $\mathrm{K}$ (1986) New frond formation in Laminaria hyperborea (Phaeophyta) a photoperiodic response. Br Phycol J $21: 269-273$

Lüning K (1988) Photoperiodic control of sorus formation in the brown alga Laminaria saccharina. Mar Ecol Prog Ser $45: 137-144$

Lüning K (1991) Circannual growth rhythm in a brown alga, Pterygophora californica. Bot Acta 104:157-162

Lüning K (1992) Day and night kinetics of growth rate in green, brown and red seaweeds. J Phycol 28:794-803

Lüning K (1994) Circadian growth rhythm in juvenile sporophytes of Laminariales (Phaeophyta). J Phycol 30:193-199

Lüning K, Dieck T (1989) Environmental triggers in algal seasonality. Bot Mar 32:389-397

Madronich S, McKenzie RL, Björn LO, Caldwel MM (1998) Changes in biologically active ultraviolet radiation reaching the earth's surface. J Photochem Photobiol 46:5-19

Nultsch W. Pfau J (1979) Occurrence and biological role of light-induced chromatophore displacements in seaweeds. Mar Biol 51:77-82

Quintern LE, Horneck G, Eschweiler U, Bücker H (1992) A biofilm used as ultraviolet-dosimeter. Photochem Photobiol 63:74-78

Smith RC, Prezelin BB, Baker KS, Bidigare RR, Boucher NP, Coley T, Karentz D, MacIntyre S, Matlick HA, Menzies D, Ondrusek M, Wan Z, Waters KJ (1992) Ozone depletion: ultraviolet radiation and phytoplankton biology in Antarctic waters. Science 255:952-959

Sokal PR, Rohlf FJ (1981) Biometry: the principles and practice of statistics in biological research, 2 nd edn. WH Freeman, San Francisco

Strid A, Chow WS, Anderson JM (1990) Effect of supplementary ultraviolet-B irradiation on photosynthesis in Pisum sativum. Biochim Biophys Acta 1020:260-268

Strid A, Chow WS, Anderson JM (1996) Changes in the relaxation of electrochromic shifts of photosynthetic pigments and in the levels of mRNA transcripts in leaves of Pisum sativum as a result of exposure to supplementary UVB radiation: the dependency on the intensity of the photosynthetically active radiation. Plant Cell Physiol 37:61-67

Svendsen P (1959) The algal vegetation of Spitsbergen. Nor Polarinst Skr 116

Vass I, Sass L, Spetea C, Bakou A, Ghanotakis DF, Petrouleas V (1996) UVB-induced inhibition of photosystem II electron transport studied by EPR and chlorophyll fluorescence: impairment of donor and acceptor side components. Biochemistry 35:8964-8973

Weykam G, Wiencke C (1996) Seasonal photosynthetic performance of the endemic Antarctic red alga Palmaria decipiens (Reinsch) Ricker. Polar Biol 10:589-600

Wiencke C (1982) Effect of osmotic stress on thylakoid fine structure in Porphyra umbilicalis. Protoplasma 111:215-220

Wiltens J, Schreiber U, Vidaver W (1978) Chlorophyll fluorescence induction: an indicator of photosynthetic activity in marine algae undergoing desiccation. Can $\mathrm{J}$ Bot 56: $2787-2794$

Wood WF (1987) Effect of solar ultra-violet radiation on the kelp Ecklonia radiata. Mar Biol 96:143-150

Submitted: May 12, 1999; Accepted: August 2, 1999

Proofs received from author(s): December 14, 1999 